
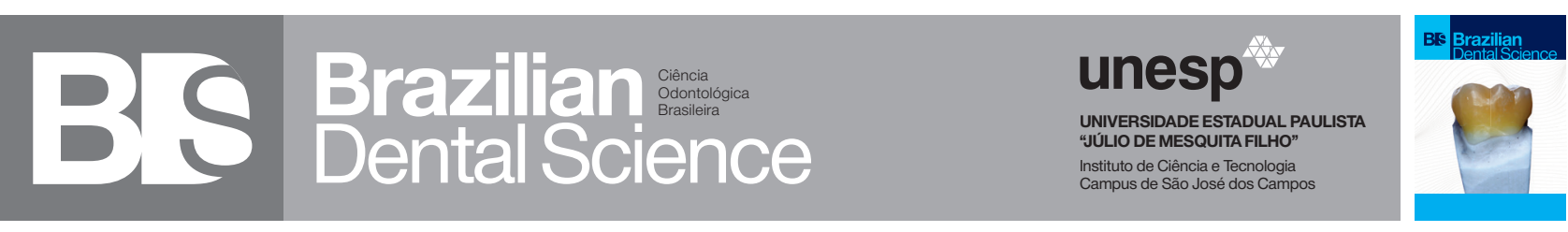

\title{
The comparison of the rate of apical displacement in curved root canals using Neoniti and RaCe files by cone beam CT Scan
}

Comparação da taxa de desvio apical em canais radiculares curvos utilizando limas Neoniti e RaCe por meio de tomografia computadorizada cone beam (TCCB)

\author{
Mostafa GODINY' ${ }^{1}$, Nafiseh NIKKERDAR ${ }^{2}$, Reza HATAM${ }^{1}$, Leila SHAHSAVAND ${ }^{3}$, Atefeh KHAVID ${ }^{2}$ \\ 1 - Endodontics Department - Faculty of dentistry - Kermanshah University of Medical Sciences - Kermanshah - Iran. \\ 2 - Oral and Maxillofacial Radiology Department - Faculty of Dentistry - Kermanshah University of Medical Sciences - Kermanshah - Iran. \\ 3 - Dentistry Research Committee - Faculty of dentistry - Kermanshah University of Medical Sciences - Kermanshah - Iran.
}

\section{ABSTRACT}

Objective: There is a high prevalence of root canal transportation in the teeth with the curve. Effect of root canal transportation on the success of root canal therapy of tooth is negative and there is no study about comparing RaCe and Neoniti files in root canal transportation. The aim of this study is assessment and comparing two different RaCe and Neoniti files to determine transportation error in various parts of root using CBCT assessment and comparing them with each other. Material and Methods: In this experimental study 50 extracted mandibular molar teeth selected. Teeth were divided randomly into two groups i.e. 25 teeth threated with RaCe file (first group) and 25 teeth threated with Neonitu files (second group). CBCT images were used to measurement thickness of dentine, before and after instrumentation that obtain from NNT viewer 6.1.0 software. Results: In the first group, the mean tooth transportation in $5 \mathrm{~mm}$ of apex was 0.15 and, in the second group, the mean tooth transportation in $5 \mathrm{~mm}$ of apex was $0.18 \mathrm{~mm}$. There was no statistically significant difference in canal transportation between RaCe and Neoniti files in five millimeters distant from apex area $(p=0.492)$ and the mean transportation from $9 \mathrm{~mm}$ of apex were 0.14 in the second group. There was no statistically significant difference in canal transportation between two groups $(\mathrm{p}=0.911)$. Conclusion: In comparison of these two rotary files, both are equally safe regarding the extent of apical transportation.

\section{KEYWORDS}

Canal transportation; Curved canals; Cone bean CT scan; Rotary file.

\section{RESUMO}

Objetivo: Existe uma alta prevalência de desvio apical em canais radiculares curvos. O efeito do desvio apical no canal radicular sobre o sucesso da terapia endodôntica é desfvorável e não há nenhum estudo comparando as limas RaCe e Neoniti em relação ao desvio apical dos canais radiculares durante o preparo. O objetivo deste estudo é avaliar e comparar duas diferentes limas, RaCe e Neoniti, a fim de para determinar o erro de desvio em várias porções radiculares através de análise por TCCB e compará-los entre eles. Material e Métodos: Neste estudo experimental, 50 dentes molares mandibulares extraídos foram selecionados. Os dentes foram divididos aleatoriamente em dois grupos, ou seja, 25 dentes preparados com as limas RaCe (primeiro grupo) e 25 dentes preparados com limas Neoniti (segundo grupo). Neste estudo para medir a espessura da dentina através do escaneamento, antes e depois da instrumentação, ao mesmo tempo, usamos imagens axiais obtidas do software NNT viewer 6.1.0. Resultados: No primeiro grupo, o desvio apical médio a $5 \mathrm{~mm}$ do ápice foi de 0,15 e no segundo grupo o desvio apical médio a $5 \mathrm{~mm}$ do ápice foi de $0,18 \mathrm{~mm}$, não havendo diferença estatisticamente significante entre as limas RaCe e Neoniti a cinco milímetros da porção apical $(p=0,492)$ e o transporte médio a 9 $\mathrm{mm}$ do ápice foi de 0,14 no segundo grupo não havendo diferença estatisticamente significante no desvio apical entre os dois grupos $(p=0,911)$. Conclusão: Os resultados indicaram que não houve diferença significativa no desvio apical médio entre dois sistemas de limas em 3, 9, 7, 5 e 11 $\mathrm{mm}$ do ápice e ambos as limas foram seguras.

\section{PALAVRAS-CHAVE}

Desvio apical; Canais curvos; Tomografia computadorizada; Limas rotatórias. 


\section{INTRODUCTION}

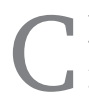
leaning and shaping of tooth's root canal is the most step of root canal therapy [12] root canal shaping is the preparation of canal conically from coronal to apical with maintenance in the main path of the canal [2]. One of the problems in preparation of root canal therapy is a deviation from the main path of root canal especially in the canals with the curve that it occurs when inflexible instruments are utilized. Deviation from the main curve of the canal may lead to excessive and inappropriate removal of dentine [3], straightening of the path of canal and formation of a ledge in dentine wall [4], excessive preparation and weakness of tooth and thus root fracture [3]. Similarly, root transportation error is one of the most prevalent problems in the canals with the curve [5]. Root transportation error may be due to inadequate cleaning of tooth canal because of remain debris and microorganisms [6] and caused poor prognosis [7] and also it may probably lead to zipping or perforation of the canal [8]. One of the important challenges for dentists is the errors that occur during operation e.g. ledge and apical transportation and losing of length workening [9]. During recent years, using NiTi files has been increased because of simple and safe in an ability to root canal shaping and also decrease iatrogenic errors canals with the severe curve [9] and this files minimize errors and tiring in operator [10] and the chance for occurrence of some errors has been decreased [e.g. transportation, zipping, ledge and strip perforation] [11] and rate success of root canal therapy has been improved compared to stainless steel hand instruments [12]. The results of various studies have indicated that NiTi rotary files have acted better than stainless steel hand instruments to keep the main curve of the canal [13-18]. The rotary systems may be multiple files or a single file. One of the Neoniti (NEOLIX, Châtres-la-Forêt, France ) single files which have been newly produced using a new machining technique (milling) of metal wire generated by Electrical Discharge Machining (EDM). One of the advantages of Neoniti is Lack of twisting effect in the root canal and it has been made from a special alloy that allows the file to become flexible. This system has been produced in three different sizes (\#20/0.08, \#25/0.08 and \#40/0.08) therefore it is recommended to use them at the speed of $300-500 \mathrm{rpm}$ and torque $(1.5 \mathrm{~N} / \mathrm{cm})$. This file has many advantages e.g. sharp cutting-edges, single-file technique and gothic tip design and made of abrasive properties [19]. One of the other types of rotary files is RaCe utilized consequently in several sizes ranging from small to large and it contains triangular section design with alternating cutting edges. It is claimed this device is not locked inside the canal and moreover cutting effect may be improved by electrochemical surface treatment. In studies about this file It has been reported that this file may keep the main curvature in the canal and it is safe for use [20-23]. With respect to the advantages of CBCT to assesment transportation [24], and high prevalence of canal transportation in canals with curve and negative effect of canal transportation in success of root canal therapy and abcsense of comparison of root canal transportation between RaCe and Neoniti files our aim was analyzing two different RaCe and Neoniti files for transportation error in various parts of tooth canal by using CBCT to assessment and comparison with each other.

\section{METHOD}

This is an in vitro study 50 first mandibular molar teeth with 15-30 degree curve that extracted because of carious and periodontal disorders were selected inclusion criteria in this study was: apex closer, vertuch anatomy type 4 (separation two canal of a single root from coronal to apical areas), the minimum root length of $18 \mathrm{~mm}$ and curve of canal (15$30^{\circ}$ ) and the exclusion criteria from this study was: Presence of external resorption, severe carious extensive to root surface, root fracture, internal resorption, canal calcification. for the selected teeth $(K \neq 10)$ files have been placed in mesiobuccal canal and radiography image was taken by parallel technique and lenght of tooth canal was recorded on tracing paper and amount of curve of canal according to the eshnaider 
technique was reported.one line trace parallel to the tooth long axis and The Second line starts from apex so that to cross with the first line on a curve of the canal [25]. Crown of teeth was measured up to length of $18 \mathrm{~mm}$ from apex and cut by a diamond disk (Switzerland, Topsent). The length workening was determined $1 \mathrm{~mm}$ less than this value for all teeth. Teeth were randomly divided into two groups including 25 teeth with RaCe file (first group) and 25 teeth with Neoniti file (second group). On the surface of the glassy jig with dimensions of $6 \times 6 \mathrm{~cm}$ [26] a wax layer was put so that apex of teeth not to be exposed to the glass. Then, samples were placed in triple rows and mounted by acrylic resin (Acropars, Marlic Dental, Iran). Teeth were totally mounted in 6 jigs (Figure 1). After selection and cleaning teeth from residual soft tissue and callus, teeth were clinically evaluated to absence of external reabsorption, severe extended carious to the root surface, root fracture and mature apex. Afterwards, teeth were located in formalin (10\%) for disinfection and maintenance of conditions of samples. Cavity Access was prepared by high speed rotary instrument. An Orifice of canals was found by $\mathrm{K} \neq 10$ file. Figure 2 shows teeth with the canals in which curvature is $15-30$ degree with at least $18 \mathrm{~mm}$ as selected length.

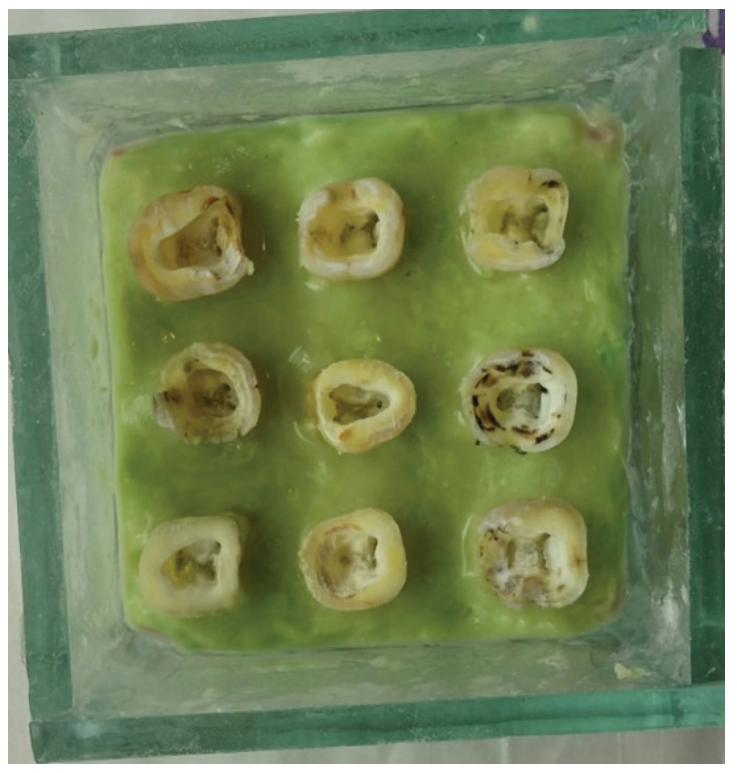

Figure 1 - Teeth mounted on the jig (18 mm).

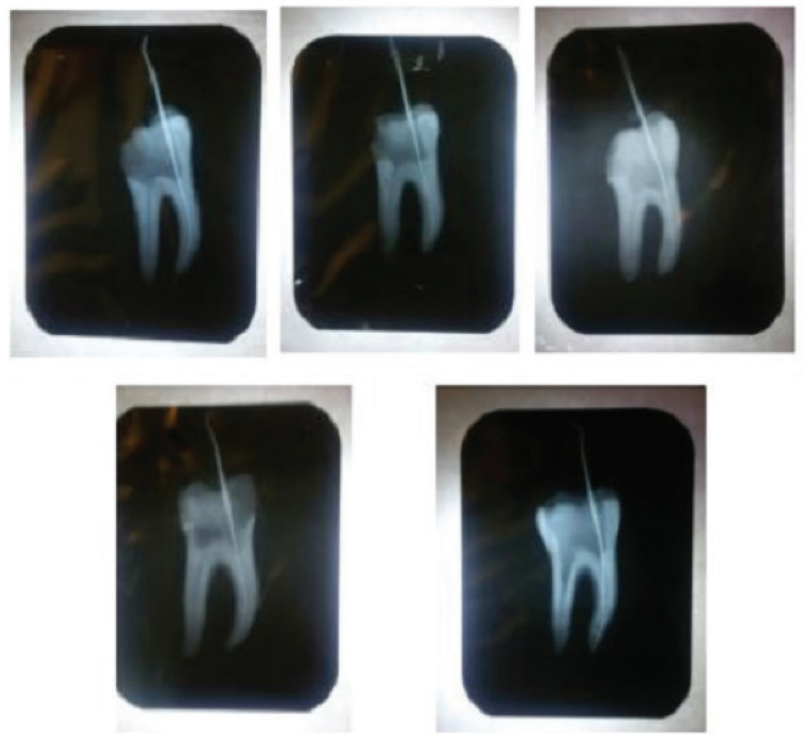

Figure 2 - Teeth with canals having 15-30 degree curvature and minimum length.

The mounted teeth were put in certain and repeatable positions in CBCT device and the water were used as a simulator for soft tissue and CBCT images were obtained before the operation. The images were obtained by Newtom VGI CBCT system (QR SRL Co. Verona, Italy) in which parameters of voxel size (axial pitch) have been designated as $0.150 \mathrm{~mm}$, the voltage of $110 \mathrm{kv}$ and $10.88 \mathrm{~mA}$ with the time period of $5.4 \mathrm{~s}$ and field of view $6 \times 6 \mathrm{~cm}$.

File Instrumentation of samples of each group was done on by specific command presented by file Manufacturing Company. The operational processes are shown in Table 1 . The CBCT images were taken from samples after an operation according to the same primary conditions in terms of direction and location of teeth in the given apparatus. Similarly, (X1$\mathrm{X} 2$ )-(Y1-Y2) formula was used for calculation of canal transportation (Table 2) [17]. 
Table 1 - The operational processes in both studied groups

Operation processes
Group
The root canal shaping was done by rotary file RaCe
(FKG, La ChauX-de-Fonds, and Switzerland). Namely,
after creating a glide path with K files $\neq 10$ and $\neq 15$ (MANI,
Japan) and irrigation the canal with sodium hypo chlorite
(5.25\%) and before using any device inside the canal, Rc
prep prep, South Korea) was utilized. Then A20 files were
4\% and 6\% taper were used respectively irrigation canal
among use of files, for removal of debris. As any file resis-
tance sensation, we exited the given file slowly from the
canal and opened the path by smaller hand instrument file
and washing and utilization of rotary file was continued to
reach to the working length and then they were irrigated
again and afterwards file $\neq 25$ was used with $6 \%$ taper to
shape the canal. The files used inside and outside of canal
during rotation. Residual Debris was removed by humid
gauze from file any time outside from the canal. The
speed was selected 500 rpm for the rotary motor to this
system with a torque of $1 \mathrm{~N} / \mathrm{cm}$. the petals of any file were
groparated from any file once until petals were terminated
for all files.

Table 2 - Definition of parameters used for the calculation of canal transportation

\begin{tabular}{|c|c|}
\hline Group & Operation processes \\
\hline $\mathrm{X} 1$ & $\begin{array}{l}\text { The minimum distance from the external wall in mesial } \\
\text { part to an internal wall in mesial part of the canal with no } \\
\text { instrumentation }\end{array}$ \\
\hline $\mathrm{X} 2$ & $\begin{array}{l}\text { The minimum distance from the external wall in mesial } \\
\text { part to an internal wall in mesial part of the canal with } \\
\text { instrumentation }\end{array}$ \\
\hline Y1 & $\begin{array}{l}\text { The minimum distance from the external wall in distal } \\
\text { part to an internal wall in distal part of the canal with no } \\
\text { instrumentation }\end{array}$ \\
\hline Y2 & $\begin{array}{c}\text { The minimum distance from the external wall in distal part } \\
\text { to an internal wall in distal part of the canal with instru- } \\
\text { mentation }\end{array}$ \\
\hline
\end{tabular}

Using NNT viewer 6.1.0 (New Tom, QR S.r.1.Co., Verona, Italy) software, axial images were displayed beside each other to measure dentinal thicknesses in scan before and after instrumentation at the same time and we could achieve length sizes of 3, 5, 7, 9 and $11 \mathrm{~mm}$ of apex by playing up or down these images and calibrations were done and canal transportation was calculated (Figures 3 to 6).



Figure 3 - Measurement of mesial and distal distances from the root to canal with no instrumentation.



Figure 4 - Measurement of mesial and distal distances from the root to canal with instrumentation. 


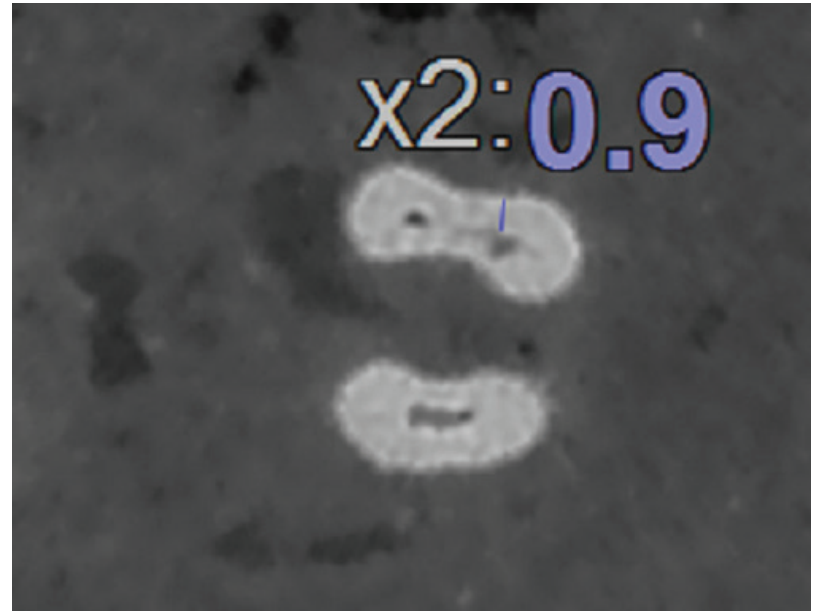

Figure 5 - Measurement of mesial and distal distances from the root to canal with no instrumentation.

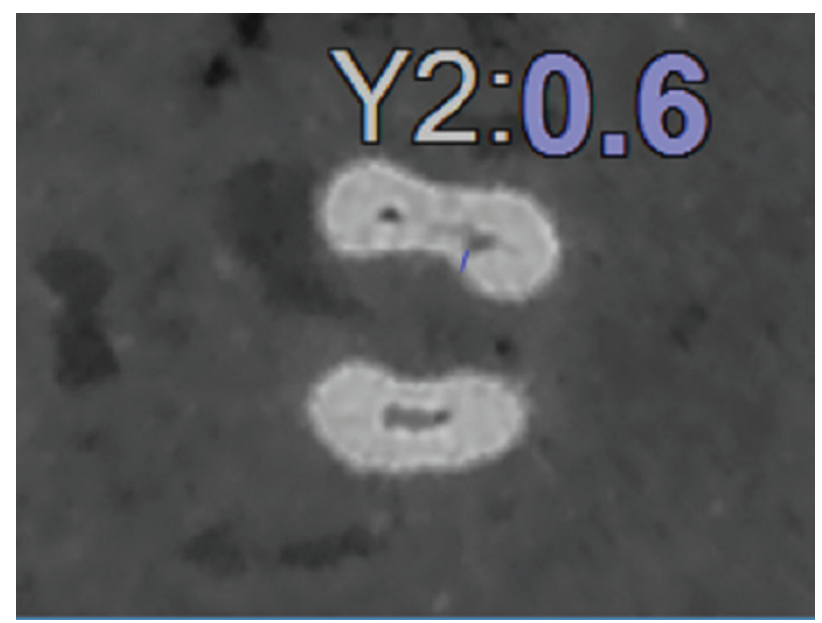

Figure 6 - Measurement of mesial and distal distances from the root to canal with no instrumentation.

The data obtained from the present study were analyzed by descriptive and inferential statistics in two parts. In the section of descriptive statistics, criteria such as central tendency and dispersion were reported with the table. In inferential statistic part, the normality of data was analyzed using the Kolmogorov-Smirnov test. With respect to the normal distribution of data (p-value > 0.05) and for comparison between two files, Independent T-test (two samples) was employed. Likewise, in order to compare canal transportation within different distances from an apex, repeated measures test was utilized. SPSS Version 18.0 (Inc., Chicago, Il, USA) software was used for data analysis. The significance level was considered at 0.05 in this study.

\section{RESULTS}

The mean transportation value $d$ in 3 $\mathrm{mm}$ distance from an apex of the first group is $(0.12)$ and the mean transportation in $3 \mathrm{~mm}$ distance from an apex of the second group is (0.14). Analysis of these data indicated that there was no statistical significant difference in canal transportation between two RaCe and Neoniti files on $3 \mathrm{~mm}$ distance from an apex $(p=0.633)$. Likewise, the mean transportation in 5 millimeters distance from the apex is 0.15 in the first group and the mean transportation rate locating at $5 \mathrm{~mm}$ distance from the apex is measured 0.18 in the second group and analyses of these data showed there was no statistically significant difference in canal transportation between two RaCe and Neoniti files in five millimeters distance from apex ( $p$ $=0.492$ ). The given mean transportation in seven millimeters from apex is 0.15 in the first group while the mean transportation in seven millimeters from apex is 0.19 in the second group. The analysis on these data indicated that there was no statistically significant difference in canal transportation between two RaCe and Neoniti files in seven millimeters distance from an apex $(p=0.256)$. The mean transportation rate in nine millimeters distance of apex in the first group is 0.15 while the rate of mean transportation in nine millimeters distance of apex in the second group is 0.14 . The analysis of data showed that there was no statistically significant difference in canal transportation among two RaCe and Neoniti files in ninemillimeter distance from apex $(\mathrm{p}=0.911)$. The mean rates of canal transportation in 11 mm distance from an apex were $0 / 13$ and 0.14 in the first and second groups, respectively. Analysis conducted on these data indicated that there was no statistically significant difference among RaCe and Neoniti files in $11 \mathrm{~mm}$ distance from the apex $(\mathrm{p}=0.754)$. 
Therefore, there was no statistically significant difference within various distances from the apex in RaCe file (0.911). At the same time no statistically significant different was seen in canal transportation from the apex in Neoniti file $(\mathrm{p}=0.378)$ (Table 3$)$.

Table 3 - Mean and standard deviation for canal transportation separately based on the type of file and distance from an apex

\begin{tabular}{|c|c|c|c|c|c|c|c|c|c|c|c|}
\hline \multirow{2}{*}{$\begin{array}{c}\text { Group } \\
\text { X1 }\end{array}$} & \multicolumn{2}{|c|}{$3 \mathrm{~mm}$} & \multicolumn{2}{|c|}{$5 \mathrm{~mm}$} & \multicolumn{2}{|c|}{$7 \mathrm{~mm}$} & \multicolumn{2}{|c|}{$9 \mathrm{~mm}$} & \multicolumn{2}{|c|}{$11 \mathrm{~mm}$} & \multirow[t]{2}{*}{$\begin{array}{c}\text { p-val- } \\
\text { ue† }\end{array}$} \\
\hline & Mean & SD & Mean & SD & Mean & SD & Mean & SD & Mean & SD & \\
\hline RaCe & .12 & .11 & .15 & .16 & .15 & .13 & .15 & .12 & .13 & .14 & 0.911 \\
\hline Neoniti & .14 & .13 & .18 & .13 & .19 & .14 & .14 & .13 & .14 & .13 & 0.378 \\
\hline p-valuef§ & \multicolumn{2}{|c|}{0.633} & \multicolumn{2}{|c|}{0.492} & \multicolumn{2}{|c|}{0.256} & \multicolumn{2}{|c|}{0.911} & \multicolumn{2}{|c|}{0.754} & \\
\hline
\end{tabular}

\section{DISCUSSION}

The aim of the current study was to compare the rate of canal displacement in tooth root by two different RaCe and Neoniti files in mesiobuccal canals of first mandibular molar teeth. The root canal shaping should be conical from coronal to apical of the tooth with keeping the main path of the canal [2]. RaCe file is one of the multi-file rotary systems with triangular cross section and alternating cutting edges. This instrument is not locked inside the canal and additionally cutting effect of this file improved by electrochemical surface treatment [20]. Vlassis $\mathrm{M}$ and Schafer E carried out a study on 48 molar teeth in maxilla and mandible with the curve (25-35degree) and concluded that Race might keep concentricity of canal better than ProTaper [22]. In other studies it was reported that RaCe files could keep the main curve in the canal and was safe to use [20-23]. The single-file rotary system may be divided according to their motion into rotating and reciprocating files. Reciproc and WaveOne files are reciprocal rotary files that cleaning root canals with one file. These files have been made of a special type of NiTi alloy called M-Wire that cause flexibility and resistance to fatigue [27]. Neoniti files have been produced using as new machining technique (miling) for metal wire by electrical discharge machining
[28]. These files are high flexibility and have not usual metallic memory of metal and fast recovery to the primary state. This propertice is probably related to employing EDM process and suitable thermal cycling used in making these files that may lead to the high flexibility of files in this system [26]. Given new Neoniti file, few studies have compared transportation rate in this file. Findings of this in vitro study are consistent with study done by Moazzami et al. [26] who have compared canal transportation of 45 maxillary molars with curved $\left(15-30^{\circ}\right)$ between two single files of Neoniti and Reciproc by using of CBCT so that both of these files are safe, but in the current study, samples have been selected from mandibular first molar where other studies have less analyzed this field and at the same time we compared among Neoniti and RaCe files as the safe files. Forghni et al. [29] assessment root canal shaping between two neolix and protaper systems in which lesser transportation was observed in the neolix group [29]. This issue is consistent with the present research. However in Forghni et al. [29] study were utilized glassy blocks instead of teeth samples and they used analysis of transportation with stereomicroscope before and after instrumentation while in present study human dental samples were used and CBCT image was obtained as the newest and most preciset technique of root canal assessment.

Also, Madani et al. [30] Evalued Neoniti and protaper transportation by using CBCT in which there was no significant difference between two groups and both files were safe. There was agreement among the results of our study but in their study maxillary molar teeth were also used. Thus we used the mandibular first molar teeth in current research. As it mentioned, the aim of the present study was to compare the rate of deviation in a mesiobuccal canal of mandibular first molar teeth using Neoniti and RaCe rotary files. The results of a comparison of transportation among two rotary files (Race, Neoniti) obtain from CBCT 
images indicated that there was no statistically significant difference in $3 \mathrm{~mm}$ distance from the apex and also no statistically significant difference was observed in distances of 3, 5, 7,9 and $11 \mathrm{~mm}$ of the apex. With respect to all of the above-said cases, both files are safe, Neoniti file is better than RaCe file because it is a single file with faster preparation speed $[22,31]$ and due to the modern technique for production. Collection of necessary samples was one of the limitations in this study and this study was done on extracted teeth and this condition is surely different from clinical conditions and cannot give additional radiation exposure to the patient and at the same time it is more difficult to manage the condition in a clinic.

\section{CONCLUSION}

In comparison of these two rotary files, both are equally safe regarding the extent of apical transportation.

\section{REFERENCES}

1. Monticelli F, Sword J, Martin R, Schuster G, Weller R, Ferrari M, etal. Sealing properties of two contemporary single cone obturation systems. Int Endod J. 2007 May;40(5):374-85. Epub 2007 Feb 27.

2. Schilder H.Cleaning and shaping the root canal. Dent Clin North Am. 1974 Apr;18(2):269-96.

3. Ingle Jl, Bakland LK. Endodontics. 5 th ed. Hamilton [Canadá]: B.C. Decker; 2002.

4. Gutmann JL. Problem solving in Endodontics. 3ed. Mosby;Maryland Heights: 1997.365p.

5. Abou-Rass M, Frank AL, Glick DH. The anticurvature filing method to prepare the curved root canal. J Am Dent Assoc. 1980 Nov;101(5):792-4.

6. Ingle Jl, Bakland LK. Baumgartner JG. Endodontics. 6th ed. Hamilton [Canadá]: BD Decker;2008. https://www.academia.edu/37337461//ngle Endodontics_6th_ed..pdf

7. SchäferE,Dammaschke T.Development and sequelae of canal transportation. Endod Top. 2006;15(1):75-90.

8. Karabucak B, Gatan AJ, Hsiao C, lqbal MK. A comparison of apical transportation and length control between EndoSequence and Guidance rotary instruments. J Endod. 2010 Jan;36(1):123-5. doi: 10.1016/j. joen.2009.09.015.

9. Peters $0 \mathrm{~A}$. Current challenges and concepts in the preparation of root canal systems: a review. JEndod. 2004 Aug;30(8):559-67.

10. Mokhtari H,Niknami M, Sohrabi A, Habibivand E, MokhtariZonouzi HR, Rahimi S, etal. Cone-Beam Computed Tomography Comparison of Canal
Transportation after Preparation with BioRaCe and Mtwo Rotary Instruments and Hand K-Flexofiles. Iran Endod J. 2014 Summer;9(3):180-4. Epub 2014 Jul 5.

11. Parashos P,Messer HH. Rotary NiTi instrument fracture and its consequences. JEndod. 2006 Nov;32(11):1031-43.

12. Alves RA, Souza JB, Goncalves Alencar AH, Pecora JD, Estrela C. Detection of Procedural Errors with Stainless Steel and NiTi Instruments by Undergraduate Students Using Conventional Radiograph and Cone Beam Computed Tomography. Iran Endod J. 2013 Fall;;(4):160-5. Epub 2013 Oct7.

13. Hulsmann M, Schade M, Schafers F.A comparative study of root canal preparation with HERO 642 and Quantec SC rotary Ni-Ti instruments. Int Endod J.20010ct;34(7):538-46.

14. JavaheriHH, Javaheri GH. A comparison of three Ni-Ti rotary instruments in apical transportation. JEndod. 2007 Mar;33(3):284-6.

15. Park H. A comparison of Greater Taper files, ProFiles, and stainless steel files to shape curved root canals. Oral Surg Oral Med Oral Pathol Oral Radiol Endod. 2001Jun;91(6):715-8.

16. Pettiette MT,Metzger Z, Phillips C, Trope M. Endodontic complications of root canal therapy performed by dental students with stainless-steel $\mathrm{K}$-files and nickel-titanium hand files. J Endod. 1999 Apr;25(4):230-34.

17. Short JA, Morgan LA, Baumgartner JC. A comparison of canal centering ability of four instrumentation techniques. J Endod. 1997 Aug;23(8):503-7.

18. Thompson SA, Dummer PM. Shaping ability of Lightspeed rotary nickeltitanium instruments in simulated root canals. Part2. JEndod. 1997;23(12):7427.

19. Dhingra A, Gupta R, Yadav V, Aggarwal N. Endodontic retreatment using single file neoniti system. Am J Oral Med Radiol. 2015;2(4):206-8.

20. Paqué F,Musch U, Hülsmann M. Comparison of root canal preparation using RaCe and ProTaper rotary Ni Ti instruments. IntEndod J. 2005 Jan;38(1):8-16.

21. Rangel S, Cremonese R, Bryant S, Dummer P.Shaping ability of RaCe rotary nickel-titanium instruments in simulated root canals. J Endod. 2005 Jun;31(6):460-3.

22. Schafer E, Vlassis M. Comparative investigation of two rotary nickel-titanium instruments: ProTaper versus RaCe.Part2. Cleaning effectiveness and shaping ability in severely curved root canals of extracted teeth. Int Endod J. 2004 Apr;37(4):239-48.

23. Schäfer E, Vlassis M. Comparative investigation of two rotary nickel-titanium instruments: ProTaper versus RaCe. Part 1. Shaping ability in simulated curved canals. Int Endod J. 2004 Apr;37(4):229-38.

24. Honardar K, Assadian H, Shahab S, JafariZ, Kazemi A, Nazarimoghaddam K, etal. Cone-beam Computed Tomographic Assessment of Canal Centering Ability and Transportation after Preparation with Twisted File and Bio RaCe Instrumentation. J Dent(Tehran).2014 Jul;11(4):440-6. Epub 2014 Jul 31.

25. Schneider SW. A comparison of canal preparations in straight and curved root canals. Oral Surg Oral Med Oral Pathol. 1971 Aug;32(2):271-5.

26. Moazzami F, Khojastepour L, Nabavizadeh M, Habashi MS. Cone-Beam Computed Tomography Assessment of Root Canal Transportation by Neoniti and Reciproc Single-File Systems. Iran Endod J. 2016 Spring;11(2):96-100. doi: 10.7508/iej.2016.02.004. Epub2016 Mar 20.

27. Shen Y,Cheung GS-p, Bian Z, Peng B. Comparison of defects in ProFile and ProTaper systems after clinical use. JEndod. 2006 Jan;32(1):61-5.

28. Taşdemir T,ErK, Yildirim T, Celik D. Efficacy of three rotary NiTi instruments in removing gutta-percha from root canals. Int Endod J.2008 Mar;41(3):191-6. Epub2007Dec 10. 
29. Forghani M, Hezarjaribi M, TeimouriH. Comparison of the shaping characteristics of Neolix and Protaper Universal systems in preparation of severely-curved simulated canals. JClin Exp Dent. 2017 Apr 1;9(4):e556-e559. doi:10.4317/jced.53476. eCollection 2017 Apr.

30. Madani Z, Soleymani A, Bagheri T,Moudi E, Bijani A, Rakhshan V.

Transportation and Centering Ability of Neoniti and protaper Instruments; ACBCT assessment. Iran Endod J. 2017 Winter;12(1):43-49. doi: 10.22037/ iej.2017.09.
31. Burklein S, Benten S, Schafer E. Shaping ability of different single-file systems in severely curved root canals of extracted teeth. Int Endod J. 2013 Jun;46(6):590-7. doi:10.1111/iej:12037.Epub 2012Dec 13.

\section{Atefeh Khavid}

\section{(Corresponding address)}

Oral and Maxillofacial Radiology Department

Faculty of Dentistry

Kermanshah University of Medical Sciences, Kermanshah, Iran.

Date submitted: 2019 Mar 07

Email: atefekhavid@gmail.com 